\title{
Hellenistik Kentlerde Kamusal Yapıların Finansmanında Olağan Uygulamalar ve Kent Eşrafının Rolü
}

\author{
The Financing of Public Buildings in the Hellenistic Polis: \\ Routine Business and the Role of City Elites
}

Ludwig MEIER*

Özet: Kamusal yapıların finansmanı, Hellenistik polis'lerde kent politikasının ayrılmaz bir parçasıydı. Buna rağmen konunun ekonomik temellerini kavramak kolay değildir. Yazıtlarda özel kişiler, memurlar ve krallar tarafından yapılan bağışlar ağılıklı yer alır. Kaynaklarda euergetismus ile sıklıkla karşılaşılması kentlerin kamusal yapıların finansmanı konusunda genel bir zayıflığa sahip oldukları şeklinde yorumlanmamalıdır. Çalışmada verilen örnekler yazıtların kaynak olarak finans tarihiyle ilgili sorular için nasıl değerlendirilebileceğini göstermektedir. Kamusal yapıların finansmanına hizmet eden kamusal gelirler ve kasalar konusunda ulaşılan bilgiler çerçevesinde konu, ana hatlarıyla açıklığa kavuşmaktadır. Kentler, kamusal yapıların finansmanı için kaynaklara az olarak yansıyan ayrı bir gelire sahip olmalıydılar. Eşrafın rolü bu arka plan ile farklı olarak değerlendirilmelidir. Onlar bağış ve kredilerle kamusal nakit para probleminin aşılmasına yardımcı oluyorlardı. Kamusal yapıların finansmanı eşraftan kişiler için kendilerini kamusal olarak ifade edebilmelerinin güzel bir yoluydu. Ama kentler onların finans gücüne bağımlı değillerdi.

Anahtar Sözcükler: Hellenistik polis, kamusal yapılar, kamusal maliye, kent eşrafı, bağışlar

Abstract: The financing of public buildings was one of the main concerns of urban politics in the Hellenistic polis. The analysis of its economic structure is however no straightforward task. The donations of individuals, office holders and kings are preponderant in the inscriptions. Based on selected examples this paper shows how inscriptions can be used for various aspects of financial history. One should not be tempted to infer a general weakness of public finance from the evident predominance of euergetism in the epigraphic record. A framework is given for the analysis of the funding of public works. Hellenistic cities are likely to have had at their disposal a great variety of public revenues and a diversified system of financial instruments which are, however, rarely reflected in the sources. The role of the city elites is to be judged with caution. They helped to bridge liquidity shortages through disbursements and loans. Donations of public buildings were a welcome means for them to publicly display themselves as benefactors, but the cities were not dependent upon their financial support.

Keywords: Hellenistic polis, public buildings, public finance, city elites, donations

Pausanias, Hellas'1 tasvir ettiği eserinin onuncu kitabında okuyucuyu Boiotia'daki Khaironea'dan alıp Delphoi'a götürür. Buradaki Panopeus kentinden çok şaşırmış bir biçimde söz eder. Çünkü Pausanias, Panopeus'un kendisine ait egemenlik alanı bulunması ve Phokis Meclisi'ne temsilci

\footnotetext{
* Dr. Phil., Alman Arkeoloji Enstitüsü, İnönü Cad. 10, Beyoğlu/İstanbul, ludwig.meier@ymail.com Bu çalışma 2011 yılında Ludwig-Maximilians Üniversitesi Eskiçağ Tarihi kürsüsünde tamamlanmış Die Finanzierung öffentlicher Bauten in der hellenistischen Polis (Hellenistik Kentte Kamusal Yapıların Finansmanı) başlıklı doktora tezinden 2012 yılında kitap olarak yayımlanmış aynı isimli çalışmanın özetidir. Bu nedenle çalışmada sadece antik kaynaklar gösterilmiş olup modern literatüre bazı istisnalar dışında gönderme yapılmamıştır.
} 
göndermesine karşın, burada bir polis'in olmazsa olmazları olarak gördüğü yapıların eksikliğine işaret ederek Panopeus'a polis denmesini biraz da küçümseme ile eleştirmektedir: Pausanias, Panopeus'un kamusal idari yapılar, gymnasion, tiyatro ve pazar yerinden mahrum olduğunu yazar. Kentte su temini için bile yeteri kadar tesis yoktur (Paus. X, 4., 1). M.S. II. yüzy1ldan bir yazarın bu satırları, Hellenistik Dönem'den itibaren kamusal yapıların, polis olgusunun fiziki boyutunun ve bir polis'in kentsel yerleşim çekirdeğinin vazgeçilmez karakteristiğinin ifadesi için geçerli bir kanundur.

Hellenistik Dönem'de, o zamana değin hiç olmadığı kadar büyük bir kentsel gelişim yaşanmıştır. Klasik Dönem'de gelişen ve uygulanan mimari form zenginliği ve Atina gibi önemli kentlerin formları geniş bir yayılım bulmuş ve şimdi küçük kentlere de girmiştir. Buna ek olarak bir dizi yeni yapı formları da ortaya çıkmıştır: Tiyatrolar ahşap konstrüksiyondan taş konstrüksiyona dönüşmüş, kentsel alanların planlanmasında ya da iki katlı bouleuterion'un gelişiminde peristilli mimari önem kazanmıştır. Bu örnekleri artırmak mümkündür.

İçlerinde kentsel kurumların bulunduğu kamusal yapıların inşası ve bunların sürekli bakımları, kuşkusuz bir polis organizasyonunun en önemli ve en detaylı, dolayısıyla en uzun vadeli görevleri olmalıdır. Gelişmiş altyapının gerçekleştirilebilmesi için ihtiyaç duyulan lojistik, sınai ve sanatsal yeterliliğin yanı sıra, elbette para ve diğer araçlar da önemliydi. August Böckh daha 1817 yılında yayımladığı ve günümüzün hala temel eserlerinden biri olan Die Staatshaushaltung der Athener adlı kitabında antik kentlerin toplumsal ve politik yapılarının finans durumları bilinmeden ve finans durumlarının da sosyal ve kamusal yaşamları hakkında bilgi sahibi olunmadan anlaşılamayacağını vurgular (Böckh, 1817/1886, 2).

Hellenistik Dönem için kentlerin kamusal finansman güçleri ile toplumsal ve politik yapıları sıkça birbirleriyle ilişkilendirilir. Daha eski araştırmacılar; doğrudan vergi olanaklarının sınırlı olması nedeniyle sürekli bir gelire duyulan ihtiyacın, halk meclisinin hareket özgürlüğünü kısıtladığı görüşündeydiler (Quass, 1993, 422). Özellikle inşa projeleri gibi şüphesiz çok masraflı olan projeler, zengin vatandaşların bağışları ile gerçekleştiriliyor olmalıydı. Bilindiği üzere Hellenistik polis'ler Roma Dönemi kentleriyle karşılaştırıldığında daha demokratik bir yapıya sahip olmakla birlikte, Geç Hellenistik Dönem'den itibaren halk meclisi olan demos'un egemenliği ve tüm yurttaşların yasa önünde eşitliği ilkesi üzerine kurulu bu yapı, kent içinde bir zümrenin politik ve sosyal imtiyazlar kazanması ile birlikte demokratik görünümlü bir aristokrasi yönünde giderek değişmeye başlamıştır (Gauthier, 1985, 53-75; Hamon, 2007). Özel şahısların onurlandırılmasına ilişkin çok sayıda yazıt ve tiyatroların oturma sıralarındaki değişimler bu sürece tanıklık ederler. Kamusal gelirlerin azalması nedeniyle zengin vatandaşların finansal güç açısından ön plana çıkmalarının bu durumun bir nedeni olup olmadığı sorunu, Hellenistik Dönem tarihinin temel problemlerinden biridir.

Aşağıda, Hellenistik kentlerin sosyal yapıları ve idari kurumları çerçevesinde kamusal yapıların finansmanı ve bununla bağlantılı süreçlerle ilgili bilgiler edinilen yazıtlardan ve antik metinlerden verilen örneklerle bu konunun aydınlatılmasına katkı sağlanacaktır.

$\mathrm{Bu}$ amaçla ilk olarak Magnesia ad Meandrum'da ele geçen bir belgeye dikkat çekilecektir (IMagnesia no. 92 b; Migeotte, 1984, 291-93, no. 91; Meier, 2012, 374-87, no. 54). Burada postumus bir onurlandırma kararnamesi söz konusudur. Bu belgeden öğrenildiğine göre, Magnesia'ya, tiyatrodaki yapı çalışmalarının başkanlığı ile görevli bir komisyon atanmıştır. Apollophanes oğlu Apollophanes ve muhtemelen onun kayınbiraderi olan Demetrios oğlu Maiandrios ismindeki bir akrabası bu komisyonun üyesiydiler. Apollophanes bu görevde iken metinde ifade edildiği gibi vaat ettiği parayı faizsiz olarak vermiştir. Apollophanes ve meslektaşı vefat edince oğlu Demetrios babasının izinden gitmiş ve yapı çalışmalarını aynı şekilde faizsiz borç verme suretiyle desteklemiştir. Zamanın geleneklerine uygun olarak Magnesia halkı Apollophanes'i resmi olarak övmek için onun bronz bir heykelini tiyatrodaki en görünen alana yerleştirerek 
onurlandırmayı ve ismini düzenli olarak kent yarışlarında tebliğ etmeyi kararlaştırmıştır.

$\mathrm{Bu}$ tip kararnamelerde ilan edilen onurlandırmaların nasıl finanse edildiğine dair hükümleri de bulmak mümkündür, buna göre Demetrios'un kendi heykelinin yapımına yönelik masrafları kendi kesesinden veya kentin kasasından değil, tiyatronun yapımı için ek bir halk kararnamesi ile tanzim edilmiş olan gelir kaynaklarından tahakkuk eden paralarla karşılaması yönünde karar alınmıştır. Kararnamede Demetrios'a kendi heykeli için bu parayı kullanma yetkisinin verilmiş olması, açık bir biçimde ifade edilmese de onun kamusal bir görev ile bu paraların tasarruf hakkını elinde bulundurduğu şeklinde yorumlanabilir.

Ancak böyle bir belgenin kaleme alınış şekli bizleri yanıltmamalıdır. Hellenistik onurlandırma kararnameleri için tipik bir kompozisyon olan bu metin, tamamen Apollophanes'i hizmetlerinden dolayı övmek amacıyla düzenlenmiştir. Yalnızca bir yan cümleden onurlandırmanın Magnesia ad Meandrum'daki tiyatroya yardım amacıyla bağlantılı kamusal gelir kaynaklarından finanse edildiği öğrenilmektedir. Tiyatro ise tamamen kamusal paralardan finanse edilmiştir. Apollophanes'in onurlandırılma nedeni, kamusal kasanın sıcak para probleminin borç verme ile aşılması ve bu borcun geri ödemesinden alınacak faizle elde edilecek kazançtan feragat edilmiş olmasıdır.

$\mathrm{Bu}$ tip çıkarımlar, Karia'daki Olymos'ta yer alan bir yazıttan da yapılabilmektedir (I. Mylasa no. 896 [=Blümel, 1989, 8-9]; Migeotte, 1992, 236-241 no. 75; Meier, 2012, 416-418, no. 67). Bu metin, M.Ö. II. yüzyılın 2. yarısında gerçekleşen ve büyük ihtimalle Olymos Leto Tapınağı'nın yıllık bakım ve onarımı ile bağlantılı kamusal bir bağış aksiyonunu belgelemektedir. Epidosis denilen ve genellikle yapı faaliyetleri için para elde etmek amacıyla gerçekleştirilen umumi bağış kampanyaları Hellenistik Dönem epigrafik kaynaklarında sıkça belgelenmektedir. Bir epidosis çerçevesinde bir kentin vatandaşları, halk meclisi kararnamesi ile belirli bir amaç için para bağışını temin ediyorlardı. Bağış aksiyonuna katılanlar, halk meclisi toplantısında bağışlarının miktarı konusunda formel bir vaatte bulunuyorlar ve daha sonra ilgili memurlara belirlenen tarihte parayı ödüyorlardı.

Metinde bir bağış aksiyonuna katılanlar için öngörülen tipik onurlandırmalar bulunmaktadır. Haznedara, rahip ve kanun koruyucular nezaretinde bağışta bulunanların isimlerinin ve bağış miktarlarının, muhtemelen söz konusu tapınakta aranması gereken mermer bir duvara yazılması için başvuruda bulunulmuştur. Aynı zamanda metin, bir isim listesi formunda bağışta bulunanların onurlandırmalarının nasıl finanse edildiğine dair bir nizamname de içermektedir. Onurlandırma giderlerinin, tapınağın o yılki bakım ve onarımı için ayrılmış paradan karşılanması yönünde karar alınmıştır. Böylelikle bir tiyatro yapımı amacıyla ayrılan kamusal paralardan Apollophanes için bir onurlandırmanın yapıldı ̆̆ı Magnesia ad Meandrum'daki gibi, Olymos’ta da bağış sahiplerinin isimlerini içeren bu yazıtın hazırlanmasına yönelik masraflar, bir tapınağın bakımı için ayrılan kamusal paradan karşılanmıştır.

Magnesia ve Olymos'tan gelen kararnameler, ilgili yapıların finansmanı hakkında bilgi vermek için değil bu bağlamda hizmette bulunan vatandaşları onurlandırma amacına yöneliktir. Buna rağmen, bu kararnamelerde kamusal yapıların finansmanının halk meclisinin kararı ile sağlanması için takip edilen rutin mekanizmaya dair bilgiler de elde edilmektedir.

$\mathrm{Bu}$ noktada, şimdiye kadar dikkat çekilen konularla bağlantılı olarak aşağıda yapılacak açıklamalar ve sonuç tartışmasının daha iyi anlaşılabilmesi için şu üç ana konuya açıklık getirmek yerinde olacaktır:

- Bu türden karar verme süreçlerini tam olarak formüle etmek mümkün müdür?

Aynı şekilde, her iki belgeden de memur ve vatandaşların borç verme ya da hediye etme ve bağışta bulunma yoluyla kamusal yapıların finansmanına katıldıkları bilinmektedir. Bu noktada iki soru daha yöneltilebilir: 
- Vatandaşlar kamusal yapıların finansmanı için temelde hangi kaynaklara sahipti ve bunlar nas1l ve neden belgelendirilirdi?

- Kent eşrafi kamusal yapıların finansmanında hangi rolleri oynuyordu ve bu nasıl değerlendirilmelidir?

Birinci sorunun tartışması için Karia'daki Iasos'tan kent rahipliği göreviyle ilgili bir kararname örnek olarak verilebilir (IIasos no. 219; Meier, 2012, 412-414, no. 65). Kararname doğru bir idareyi yeniden tesis etmeyi amaçlıyordu; bununla birlikte yazıtın ilgili bölümlerinin günümüze ulaşmamış olmasından ötürü, idareyi bozan bu problemlerin nereden kaynaklandığı açık değildir. Kararnameden özel kişilerin yüksek memuriyetlere, rahip ve diğer memurları şikayet etme olanağına sahip oldukları öğrenilmektedir. Böylelikle muhtemelen rahiplerin ve diğer memurların daha sıkı bir biçimde kontrol altında tutulmaları sağlanıyor olmalıdır. Bundan başka, kutsal alanların süresiz bakım ve onarımlarının düzenlenmesi, kararnamenin bir diğer konusuydu. Neopoioi (tapınak yapanlar) bir kararname örneği hazırlayacak ve bir sonraki ay bunu halk meclisinde oylamaya sunacaktı. Kararname örneğinin konusu, yeni gelir kaynaklarının yaratılmasıydı. Özel kişiler bu bağlamda tamamlayıcı, yenilenebilir ve rekabete açık önerileri tartışma için halk meclisine sunabilirlerdi.

Belgeden kesin bir sonuç çıkarmak başka bilgilerin eksik olması nedeniyle kolay değildir. Yönetim konusundaki hataların giderilmesi ve kutsal alanların bakımı için gerekli olan yeni parasal kaynakların oluşturulabilmesi konularının birlikte anılması, muhtemelen her iki mevzunun birbiriyle yakın ilişkisini göstermektedir. Burada ihmal ya da makamı kötüye kullanma nedeniyle kaybolmuş olan gelir kaynaklarının yeniden temininin söz konusu olduğu düşünülebilir.

Yukarıda sözü edilen yazıt kamusal bir yapının finansmanına dair bir kararnamenin hangi şartlar altında vücuda geldiğini gösterirken Troas'taki Skepsis'te ele geçen bir belgeden ise bu tip kararnamelerin içeriği kavranabilmektedir (Wilhelm, 1903, 54-57 no. 16; Meier, 2012, 326331 no. 46).

Kararnamenin konusu, Dionysios onuruna her yıl oyunlar düzenlenmesidir. Oyunlar için uygun mimariye sahip mekanlara ihtiyaç duyulduğundan tiyatronun yenilenmesi gerekmiştir. Böylelikle ilk olarak eski oturma basamakları sökülmüş ve cavea yeniden eğimlendirilmiştir. Basamakların artık tam olarak olmaları gerektiği hizada durmadıkları ihtimali vardır ki yeni bir temellendirme çalışmasına ihtiyaç duyulmuştur. Ayrıca yeni bir proskenion'un inşası planlanmış ve bunun için bir yapı komisyonu oluşturulmuştur. Bundan başka, cavea'yı çevreleyen dört arşın yüksekliğinde ve bir geison ile süslü duvarın inşasına da karar verilmiştir.

$\mathrm{Bu}$ kararnamenin finansla ilgili kısımlarına gelinecek olunursa; epigrafik belgelerden yola

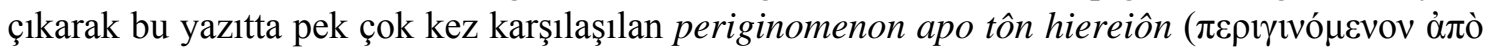

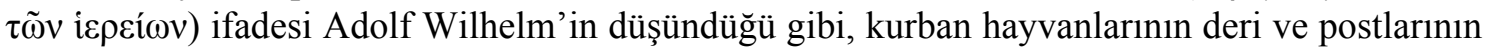
satışından elde edilen gelirlerden arta kalan meblağa karşılık geliyor olmamalıdır. Léopold Migeotte'tan yola çıkarak (Migeotte, 1995, 84), bu ifade ile muhtemelen kurban hayvanlarının alımı, ama kesinlikle kültsel amaca hizmet ile bağlantılı bir fondan, arta kalan paralar kastediliyor olmalıdır. Bu yüzden bu amaçla bağlantılı fondan daha sonra yıllık 200 altın stater ayrılan oyunlar için gereken para kullanılmıştır. Bu 200 altın stater'den geriye kalan, tiyatronun gelecek yıllarda devam edecek bakım ve onarım çalışmaları için harcanmış olmalıdır.

Birinci festival oyunlarının hazırlıkları ile cavea, sahne binası ve çevre duvarı gibi bununla bağlantılı yapı çalışmaları için beklenenden daha yüksek bir meblağa ihtiyaç duyulunca kurbanlık hayvan alımında önceki iki yıldan geriye kalan para bu amaçlar doğrultusunda kullanılmıştır. Ama buna rağmen masraflar karşılanamazsa, haznedar eksik miktarı kasadan tahsis edecektir. Sonuç olarak Skepsis vatandaşları bir tiyatronun onarımı ve sürekli bakımını, yeni bir bayramdan sonra doğrudan dinsel ihtiyaçlarından kaynaklanan bir görev olarak benimsemişler ve bu 
nedenle Skepsis kentinin hesaplarında, festival ve bununla ilgili yapılar daima kültsel amaçlı bir hesap kalemi altında yer almıştır.

İkinci temel sorun olan kent vatandaşlarının kamusal yapıların finansmanı için temelde hangi gelir kaynakları üzerinde tasarrufları olduğu konusuna gelince; epigrafik belgeler ve antik kaynaklar irdelenmeksizin bu konu anlaşılmaya çalışılırsa, Hellenistik polis'lerde kamusal yapıların temelde krallar ve karşılığında kamusal onurlandırmalar alan zengin vatandaşlar tarafından ödendiği manzarasıyla karşılaşılır. Bununla birlikte, Léopold Migeotte kamusal bağışların genellikle sadece az bir miktarı karşıladığını ve her şeyden önce ortak hareket karakteri taşıdığını göstermiştir (Migeotte, 1992, 349-356). Bu durumu bir örnekle açıklamak gerekirse; M.Ö. 200 yılında Boiotia'daki Tanagra'da Demeter ve Kore kutsal alanının merkeze taşınması için bir tapınak yapılması planlanmıştır. Bu amaçla kültle yakından bağlantılı bayanlar tarafından bir bağış kampanyası düzenlenmiş ve bu kampanya toplamda 473 drakhme'lik bir meblağ getirmiştir (Reinach, 1899; LSCG 72; Migeotte, 1992, 75-81 no. 28; Meier, 2012, 227 232 no. 16). Bu miktar şüphesiz sembolik bir rakam olmalıdır. Bununla birlikte bu girişimin toplamda ne kadara mal olduğu konusunda bir bilgiye sahip değiliz.

Bu sebeple şu soru yöneltilebilir: Kişilerden sürekli bir biçimde kanunlarla tahsil edilen vergiler ile ayni ödemeler ve harçlar ne oluyordu? Modern toplumlar gibi Hellenistik polis'ler de o zamanki gelir kaynaklarını tasarruflarında bulunduruyorlardı. Bütün bu harçlar mültezimlere kiralanan vergiler yoluyla akıyordu; bunlar merkezde toplanıyor ve sonra tek tek farklı kasalara dağıtılıyordu. Atina, Delos ve Miletos için gelirlerin dağılım mekanizması iyi bir biçimde belgelenmektedir.

Kaynaklarda, kamusal yapıların finansmanı amacı ile doğrudan bağlantılı, düzenli vergi ve harçlardan alınan gelirlere dair tek bir bilgi dahi bulunmamaktadır. Bu tespit özel bir açıklama gerektirmez. Bu girdi topluma birincil derecede gelir elde etmeye hizmet eden vergidir. Vergiler bir amaçla bağlantılı olarak alınmazlar ve bir bedel talebine de neden olmazlar. Birkaç istisna dışında bu durum Hellenistik Dönem polis'leri için de geçerlidir.

Yalnızca kamusal yapıların finansmanı için tahsil edilen dolaylı vergiler ya da özel harçlar belgelenmemektedir. Belgelerde, pek çok durumda sadece kentin bütün gelirlerinden, arta kalan kazançtan ya da kamusal kasadan yapılan harcamalardan finanse edilen yapım ve bakım-onarım çalışmaları zikredilmektedir. Buna karşılık kamusal yapıların finansmanı amacıyla dolaylı bağlantıl1, kesin ve vurgulu olarak anılan vergi ve harçları formüle etmek mümkündür. Bu, bir yap1 projesinin gerçekleştirilmesi için gerekli sıcak paranın kent kasasından kredi ile karşılanması halinde ortaya çıkan bir durumdur.

M.Ö. 279-221 yılları arasında Halikarnassos'ta bu şekilde bir stoa inşa edilmiştir (GIBM 4, no. 897; OGIS no. 46; Migeotte, 1984, 322-325 no. 103; Meier, 2012, 399-404 no. 61). Bu yapının finansmanı kamusal bir borçlanma yoluyla sağlanmış olmalıdır. Kamusal borçlanma, halk toplantısı kararnamesi ile alınan ve aynı koşullarda geri ödenecek bütün borçların yekûnunu kastetmektedir. Kent cemaati, burada özel kişilerden ya da başka bir tüzel kişilikten oluşan ve sanki bir dış polis'i andıran alacaklı bir grubun karşısındaki verecekliyi temsil etmektedir. Kamusal borçlanmalar için çıkarılmış olan kararnameler, kamusal bağışlar hakkındaki kararnameler ile şekilsel olarak büyük benzerlikler göstermektedir. Her ikisi de bir borçlanmada pay sahibi olan alacaklıların isimlerinin bir listede ilan edilerek onurlandırılmalarını ifade etmektedir. Bu durum, Halikarnassos'ta bir stoa'nın inşasına dair ilgili bir belgede de söz konusudur. Eğer alacaklılar en az 500 drakhmai faizsiz borç vermişlerse verilen meblağın yüksekliğine göre isimlerinin sıralandığı bir listenin yeni inşa edilen stoa'ya asılması sureti ile bu onurlandırmanın tadını çıkaracaklardır.

Kayıtlı paranın henüz yabancı olduğu bir ekonomik sistemde kentler, finansal sorumluluklarını yerine getirebilmek için sürekli bir biçimde yeterli miktarda nakit gelire yani peşin paraya 
ya da yeterli kamusal gelir akışına sahip olmak durumundaydılar. Büyük yapı projeleri gibi olağandışı bir ihtiyacın ortaya çıkması durumunda ise kredi alma seçeneği bulunmaktaydı. Kentin kredi almasının en esaslı belirtisi ekonomik kaynakların kaydırılmasıydı. Kredi alan için daha erken bir zamanda gelirini kısa vadeli yükseltmek ve ihtiyacını karşılamak mümkündü. Buna karşın gelecekteki geri ödeme, gelirini düşürecekti. Kredi alanın daha erken bir zamanda elde edeceği avantaj, faiz formundaki harcamalarla bağlantılıydı. Sorunlu alacaklının faizden feragat etmesi halinde kendisinin ne kadar haysiyetli olduğunu gösteren bir onurlandırmaya layık olduğunu gösterirdi.

Halikarnassos'ta hangi kent gelirlerinin stoa için alınan kamusal borçların geri ödemesine tahsis edileceği konusunda ilgili belgeden öğrenildiğine göre; bunlardan biri malın değerinin $\% 2$ 'si oranında alındığı öğrenilen ithalat-ihracat vergisi pentekoste, bir diğeri ise belki de memurlar tarafından anlaşmaların yemin ile teminat altına alınması için tahsil edilen harçtır. Ayrıca şehrin idaresi için var olan bütçe kaleminden 1 talanton tutarında gelir ile stoa'nın daha önceki yapısının yıkımından elde edilen yapı malzemelerinin satışından elde edilen karın da buna eklendiği öğrenilmektedir.

Aynı zamanda bu belgeden, stoa ile eş zamanlı olarak ya da bundan kısa bir süre önce bir meclis binasında yapı çalışmaları gerçekleştirildiği ve kentte birçok heykel dikildiği öğrenilmektedir. Bu işler için alınan kredi henüz geri ödenmeden stoa'nın yenilenmesi için bir kez daha borçlanılmıştır. Bütün alacaklılara aynı kamusal gelir kaynakları, ödeme garantisi olarak gösterilmiştir. Daha eski borçların daha önce kapatılmasına dönük bir düzenleme yapılmıştır. Bir diğer yazıttan anlaşıldı ̆̆ kadarıyla buna ek olarak aynı zamanda bir gymnasion inşası için kent vatandaşlarından Philonikos oğlu Diodotos'tan toplam 33.400 drakhmai'lık bir yapı kredisi alınmıştır (Migeotte, 1982, 242-249 no. 77; 1984, 319-322 no. 102; Meier, 2012, 397-399 no. 60). Bu şekilde sağlam bir ekonomik kalkınma, kredilerle finanse edilen birçok yapı projesinin eş zamanlı olarak yürütülmesi ile gerçekleştirilebiliyor görünmektedir.

Kolophon'da Antigonos Monophtalmos'un yönetimi altında kentin genişletilmesi ve yeni bir çevre duvarının inşası planlanmıştır. Bunun için ihtiyaç duyulan nakit de kamusal borçlanma ile sağlanmıştır. Halikarnassos'taki gibi borcun ödenmesi ve bu ödemenin garantisi olarak hangi kent gelirlerinin kullanılabileceği tam olarak bilinmektedir: Bunlardan biri muhtemelen tahıldan alınan doğal bir harç olan karpos, mera vergisi emphorbia, olasılıkla balıkçılıktan elde edilen gelirden \%20 oranında alınan pempte' dir (Meritt, 1935, 372-377 no. 2; Migeotte, 1984, 282-287 no. 87; Meier, 2012, 369-372 no. 53).

Dikkate değer olan, Halikarnassos ve Kolophon'dan her iki belgede de adı geçen vergiler ve harçların hypotheke olarak adlandırılmasıdır. Bu ifade kentin alacaklılara, alınan borcu bu gelirlerden geri ödemeyi garantilediği anlamına gelmektedir. Alacaklılar kent tarafından yapılacak ödemenin gecikmesi durumunda, gelir kaynaklarına el koyarak bunların gelirlerinden alacaklarını temin edebilirlerdi. Kent bu şekilde, kredi verenlere gecikme durumunda alacaklarını bu gelirlerden temin etme hakkını tanıyordu. Aynı zamanda polis böylelikle alacaklıların haciz haklarını sınırlandırarak onların sadece sözü edilen gelir kaynakları üzerinde haciz hakkına sahip olmalarını sağlıyordu. Belgelerde belirli vergiler ve harçlar yapı finansmanı bağlamında kamusal borçlanma ve kredi verme çerçevesinde, borç ödeme ve ödeme garantisi konularını düzenlemek amacıyla anılmaktadır. Vergiler ve harçlar, o dönemin toplumları için önemli gelir kaynakları olmalıdır. Aksi halde kamusal yapı finansmanına dair yazıtlarda bunlardan söz edilmezdi.

Şimdi üçüncü ana konuya, yani kent eşrafının kamusal yapıların inşasındaki rollerine değinilecektir. Burada eşraf sadece makam sahibi olanlar ve rahiplerle sinırlandırılacaktır. Yukarıda değinilen Magnesia ad Meandrum'dan Apollpohanes'in verdiği faizsiz yapı kredisinden dolayı fevkalade onurlarla onurlandırılmasının kararlaştırıldığ kararnameyi hatırlayacaksı- 
nız. Kaynaklar; makam sahiplerinin görev zamanlarında, görev alanları çerçevesinde ortaya çıkan belli harcamaları bağış olarak kendi ceplerinden yaptıklarını düzenli bir biçimde belgelemektedir.

Ama bu durum sıradan bir gereklilik olarak değerlendirilmemelidir. M.Ö. IV. yüzyılda Thessalia'daki Pharsalos'ta iç savaşa benzer bir durum ortaya çıktığında vatandaşlar kamusal finansın tüm idaresini Polydamas'a bırakmışlardı. Bize bu durumdan söz eden Ksenophon, Polydamas'ın kamusal kasadaki bu sıkıntılı dönemi kendi cebinden yaptığı harcamalarla aştığını ve kasaya yeniden yeteri miktarda gelir akmaya başlar başlamaz bu parayı geri aldığı bilgisini de bizimle paylaşmaktadır (Ksen. hell. VI. 1. 2-3). Bu Ksenophon'a çok normal görünmektedir: Polydamas ona göre, bu uygulamasına rağmen dürüst ve saygıdeğer bir biçimde davranmıştır.

Epigrafik belgeler memurların özel servetlerinden yaptıkları ve finans raporlarına işlemek durumunda oldukları ödemelere dair bilgiler içermektedir. Bu belgeler genellikle yapılan harcamaların geri ödenmesinden feragat edildiğinin vurgulu olarak ifade edildiği onurlandırmalardır. Böyle bir metni, symmoria başkanının koro gösterilerinin giderlerini kendi cebinden karşıladığ 1 ve bunu ortak kasaya fatura etmediğini Teos’tan biliyoruz (CIG 3066). Boiotia'daki Lebadeia'dan M.Ö. 80-50 yılları arasında festival başkanlığı yapmış olan Ksenarkhos, görevinin sonunda bir hesap raporu hazırlamış ve burada kurbanlar ve oyunlar için bütün giderleri kendi cebinden karşıladığını belirtmiştir (Vollgraf 1901, 365-378 no. 19). Hizmetli ve bir yazıcının maaşları ile kendi hesap raporlarının, şampiyon listelerinin ve kararnamelerin kaydı için tahsis edilen bir memuriyetin giderlerini fatura etmeden kendisi karşılamıştır. Ksenarkhos'un bütün bunları vurguladığı belge, onun bu tutumunun bir istisna olduğunun ifadesidir. Memurlar tarafından memuriyetleri çerçevesinde karşıladıkları harcamaların kendilerine geri ödenmesi kuraldı. Ksenarkhos'un bu tutumu, 300 yıldan fazla bir süre önce Atina'nın duvar yapımı görevlisi olarak hizmet vermiş olan Demosthenes'ten farklı değildir. O da duvar yapımı için geri almadığ 500 mina'lık bir bağışta bulunduğunu çevresine asla unutturmamıştır (Aiskh. III. 17; Demosth. XVIII. 111. 113).

Buna karşın, borcun geri ödemesinde ne zikredilmeye ne de kesinlikle onurlandırılmaya değer olmayan ancak buna rağmen epigrafik belgelerde iz birakan rutin uygulamalar olmalıdır. Burada, M.Ö. 116/115 yılında Salamis'in Atinalı kolonistlerinin, kutsal alanın restorasyonu ve bir eksedra inşası ile ilgili bir belge örnek olarak verilebilir (IG $\mathrm{II}^{2}$ no. 1228; Meier, 2012, 206209 no. 9). Bu proje için yapı çalışmalarının organizasyonu ile ihaleden sorumlu üç kişilik bir komisyon kurulduğu öğrenilmektedir. Bunlar aynı zamanda fatura işlerinden ve yapı projeleri çerçevesinde elde edilen gelirlerin ve onlar tarafindan gerçekleştirilen bütün harcamaların kaydından da sorumluydular. Esas itibariyle yapı çalışmaları, kolonistler tarafından yapılan bağışlar ile finanse edilerek yürütülüyor olmalıydı. Dikkate değer olan, paraya ihtiyaç duyulduğu durumlarda yapı komisyonu üyelerinin özel teşebbüsten para temin etmesidir.

Böyle bir durum kesinlikle ortaya çıkabilirdi. Bu, Mylasa'dan kutsal alanın ve kamusal yapıların başkanının onurlandırıldı $\breve{1}$ eş zamanlı bir kararnameyle de belgelenmektedir (I. Mylasa no. 106; Meier, 2012, 414-416 no. 66). Otorkondeis phyle'si tarafından yapı çalışmalarının finansmanı için belirlenmiş olan gelir kaynakları istenen meblağa ulaşmamıştır. Bunun nedeni kararnameden çıkarılamamaktadır. Geç kalmış bir ödeme ya da vergi iltizam sistemi veya iklim değişikliklerinin neden olduğu olumsuzlukla bir sıcak para probleminin bu durumun sebebi olduğu düşünülebilir. Thargelios oğlu Antiokhos, olasılıkla surlar ve kutsal bir yapı ile ilişkili bir projede epimeletes olarak görev almıştır ve bu sıkıntılı dönemi özel bir teşebbüsten borç alarak aşmıştır. İlgili metinde geçen prohieto to argyrion ifadesi ve bunun epigrafik belgelerdeki diğer paralelleri Antiokhos'un bu paraların geri ödenmesi arzusunda olduğunu göstermektedir. Böyle bir durum için Salamis'te de tedbirler alınmış ve yapı komisyonunun yapı çalışmaları için ödünç vereceği paralar ve aynı zamanda bunun geri ödemesi kesin ve açık bir biçimde ifade edilmiştir. 
Son olarak kamusal yapıların euergetes'ler aracıllğıyla finanse edilmesinden söz edilecektir. Yapı bağışları, M.Ö. III. yüzyılın sonlarına doğru kent surlarında deprem neticesinde meydana gelen zararı gidermek için para yardımında bulunan Telos'tan Aristomenes için düzenlenmiş onurlandırmanın gösterdiği gibi, esas itibariyle halk meclisinin talebi üzerine gerçekleşmekteydi. Bununla birlikte, özel bir bütçeden kamusal bir binanın yapımı ya da tadilatı için bağıșta bulunma talebi hayırseverin doğrudan kendisinden de gelebilirdi. Bu durum; Atina'dan Asklepios Rahibi Diokles (IG II ${ }^{2}$ no. 1046; Meier, 2012, 191-194 no. 3), Oropos'tan Amphiaraos'un eski Rahibi Eubiotos (IG VII no. 412; IOropos no. 294; Meier, 2012, 224-226 no. 15) ve Thasos'tan tapınak bakıcısı olarak görev yapmış ve çeşitli rahiplikler üstlenmiş olan Epie (Salviat, 1959; Meier, 2012, 311-313 no. 39) için çıkarılan onurlandırma kararnamelerinde açık bir biçimde görülmektedir. Bunların her üçü de kutsal alanlarında ve tapınaklarındaki kapı yapılarını restore ettirmişlerdir. Metinler açık bir görüş birliğini göstermektedir. Diokles ve Eubiotos meclis toplantısında yapılarda meydana gelen hasarları beyan etmekte, hasarları kendi ceplerinden tadil ettirmek istediklerini dile getirmekte ve bunun için izin istemektedirler. Thasos'tan Epie de aynı biçimde hareket etmiş olmalıdır.

Belgelerde yap1 sahipleri için yapılara bir adak yazıtı yerleştirileceği ya da onların lütuflarına karşın başka kararnameler yayımlanacağı vurgulanarak ifade edilmektedir. Yapım ve restorasyon çalışmalarının kişiler tarafından finansmanından sonra yerleştirilmiş olması gereken adak yazıtlarının metni, bazen kelimesi kelimesine aynı kalıbı içerirdi. Benzer bir durum Kalymnos'tan da bilinmektedir (Tit. Cam. no. 52). Burada en yüksek memur olan Aristias oğlu Aratokritos M.Ö. III. yüzyılın ikinci yarısında Apollon kutsal alanında bir sahne binası ve bunun önünde uzanan bir podyum inşa ettirmek için ricacı olmuştur. Kendisine inşa izni ve ayrıca yapı çalışmalarının bitiminden sonra onurlandırma kararnamesi ve buna uygun bir adak yazıtının sahne binasına yerleştirilmesi için de izin verilmiştir. Sestos'tan Menas oğlu Menas ilk olarak gymnasiarkhia üstlenmiş, diğer pek çok hizmetin yanı sıra, bir kaldarium inşa ettirmiş ve halk meclisinden bir yazıt aracılığıyla bunu ebedileştirme hakkı almıştır (ISestos no. 1).

Kamusal bir yapının üzerine adak yazıtı yerleştirilmesi kendiliğinden gerçekleşen bir olay değildir. Yazıt için yapı sahibi tarafından başvuruda bulunulur ve kent meclisinde yapılan görüşmeler sonucunda karara bağlanırdı. Hayırseverler, kentin kamuoyunda cömertlikleri ile ilişkili olarak 'iyi ve erdemli' kişiler ve kimi zaman da dini bütün rahipler olarak tanınmak için görkemli yenileme ve onarım çalışmaları gerçekleştiriyorlardı.

Her şeyden önce rahiplere ve memurlara fevkalade ayrıcalıklar ve onurlar bahşetmek sebebiyle vücuda gelen adak yazıtı formundaki kararnamelerde, yapıların kötü durumları yer yer çok etkili bir biçimde tasvir edilmiştir. Bu şekilde tahrip olan ana kapılardan, yıkılan kutsal alanlardan, agora' daki ihmal edilen ve çöken yapılardan, kanatsız kapılardan, kapatılan girişlerden, bir gymnasion'a yakışmayan durumdaki mekanlardan haberdar olunmaktadır. Bu tablo çoğu kez gerçeğe uygundur. Bununla birlikte, bu şahsiyetlerin icraatlarının böylelikle daha pırıltılı bir biçimde gözüktüğü de aşikardır.

Yazıtların, Geç Hellenistik polis'lerin yapı çalışmaları için yeteri kadar paraları olup olmadığının anlaşılması için yeterince güvenilir kaynaklar oldukları konusu şüphelidir. Bunun nedeni, yukarıda sözü edilenlerin yanı sıra epigrafik belgelerin M.Ö. II. yüzyılın ortalarından itibaren idari ve finans konularından değil de daha çok onurlandırma ve bağışlardan söz ediyor olmasıdır. 


\section{KAYNAKÇA}

Aiskh. Ed. V. Martin \& G. de Bode. Eschine. Discours. Vol. 2. Paris: Les belles Lettres. 1928.

Blümel, W. (1989). "Neue Inschriften aus der Region von Mylasa. Mit Nachträgen zu IK. 34-35”. EA 13, 1989, 1-15.

Böckh, A. (1817/1886). Die Staatshaushaltung der Athener. Dritte Auflage und mit Anmerkungen begleitet von Max Fränkel. Berlin: Georg Reimer.

CIG Corpus Inscriptionum Graecarum. Berlin 1828-1877.

Demosth. Ed. W. Rennie. Demosthenis orationes. Vol. 3. Oxford: The Clarendon Press. 1931.

Gauthier, Ph. (1985). Les cités grecques et leurs bienfaiteurs. Paris: Duffusion de Boccard.

GIBM Ed. G. Hirschfeld. The Collection of Ancient Greek Inscriptions in the British Museum. Part IV. Knidos, Halikarnassos and Branchidae. Oxford: The Clarendon Press. 1916.

IG Inscriptiones Graecae. Berlin 1873-.

IIasos. Die Inschriften von Iasos (Inschriften griechischer Städte aus Kleinasien 28). Ed. W. Blümel Bonn: Dr. Rudolf Habelt GmbH. 1985.

IMagnesia. Die Inschriften von Magnesia am Maeander. Ed. O. Kern. Berlin: Speemann. 1900.

IMylasa. Die Inschriften von Mylasa. Teil I: Inschriften der Stadt (Inschriften griechischer Städte aus Kleinasien 34). Ed. W. Blümel. Bonn: Dr. Rudolf Habelt GmbH. 1987.

IOropos. Hoi epigraphês tou Oropou. Ed. B. C. Petrakos. Atina. 1997.

ISestos. Die Inschriften von Sestos und der thrakischen Chersones (Inschriften griechischer Städte aus Kleinasien 19). Ed. J. Krauss. Bonn: Dr. Rudolf Habelt GmbH. 1980.

Hamon, P. (2007). "Élites dirigeantes et processus d'aristocratition à l'époque hellénistique". Ed. Fernoux, H. L., \& Stein, Chr. Aristiocratie antique: Modèles et exemplarité sociale, 79-100. Dijon: Éd. Univ. de Dijon.

Ksen. hell. Ed. E. C. Merchant Xenophontis opera omnia. Vol. 1. Oxford: The Clarendon Press. 1900.

LSCG Lois sacrées des cités grecques. Ed. F. Sokolowski. Paris: Éditions E. de Boccard. 1969.

Meier, L. (2012). Die Finanzierung öffentlicher Bauten in der hellenistischen Polis. Mainz: Verlag Antike.

Migeotte, L. (1984). L'eprunt public dans les cités grecques. Québec: Les éditions du Sphinx \& Paris: Les belles lettres.

Migeotte, L. (1982). Les souscriptions publiques dans les cités grecques. Genève: Libraire Droz \& Québec: Les éditions du sphinx.

Migeotte, L. (1995). "Finances et constructions publics". Ed. M. Wörrle \& P. Zanker. Stadtbild und Bürgerbild im Hellenismus, 79-86. München: C. H. Beck.

OGIS Orientis Graeci inscriptiones Selectae. Ed. W. Dittenberger Leipzig: S. Hirzel. 1903-1905.

Paus. Pausaniae Graeciae descriptio. Ed. F. Spiro Leipzig: Teubner. 1903.

Quass, F. (1993). Die Honoratiorenschicht in den Städten des griechischen Ostens. Untersuchungen zur politischen und sozialen Entwicklung in hellenistischer und römischer Zeit. Göttingen. Stuttgart: Franz Steiner Verlag.

Reinach, Th. (1899). "Un temple élevé par les femmes de Tanagra". REG 12, 53-115.

Tit. Cam. Tituli Camirenses. Ed. M. Segre, \& G. Pugliese Carratelli Annuario della Scuola di Atene e delle Missioni Italiani in Oriente 11-13; 141-318; 1949-1951.

Vollgraf, W. (1901). "Inscriptions de Béotie”. BCH 25, 356-78.

Wilhelm, A. (1900). "Nachlese zu griechischen Inschriften”. JÖAI 3, 40-62. 